\title{
Shiraliyeva N.A.*
}

DOI: 10.25108/2304-1730-1749.iolr.2017.52.305-311

\section{Issues of correlation of international and national law in sphere of protection of rights and freedoms of man and citizen}

\begin{abstract}
It is determined the issues of interconnection and interdependence of international and national law in sphere of protection rights and freedoms of a man and citizen.
\end{abstract}

Proposals on improving of correlations are given.

Keywords: international law; national law; rights and freedoms of a man; correlation of system.

Uniform standards of rights and freedoms of a person established by international law should be performed on domestic level, in this connection it is impossible to protect them effective without close interaction between international and national law.

International and national legal systems consist not only of positive law and also juridical practice and a set of institutions and therefore interaction of these systems covers the both normative and institutional levels.

Practice shows that correlations international and national laws face challenges that impede the protection of rights and freedoms of person. In this connection it appears an important task to study them at all stages of performance and protection human rights and freedoms.

One of these challenges is the fact that there is no consensus among the scientists in respect of interaction's mechanism of international and domestic laws in an area of human rights and freedoms protection. Ones scientists assert that

\footnotetext{
- Shiraliyeva Narmina Azer gyzy - a member of International Organization for Legal Researches, the Western University (Azerbaijan). E-mail: mopi_sid@yahoo.com
} 
human rights have an international nature and are out of state jurisdiction [3, p. 6569], and other ones, vice versa, prove that only states determine legal status of a person, i.e. establish, perform and protect human rights [1, p. 42-43]. Some authors deny division of human rights into international and domestic, supposing that human rights and freedoms are holistic and are not subjected to any division $[5, \mathrm{p}$. 26-27].

An issue on direct action of the norms of international law concerning human rights is remained a problematic, it is discussed so named "horizontal rights" of person and undertaken attempts to prove their existence [1, p. 96].

The problem is that circumstance that states often try to limit application of the norms of international law concerning human rights. In particular, in form of substantiation of so named "cultural relativism", which denies the universal human rights and substantiates a thesis that a list of person's rights, their content and opportunities of limitation are always determined with cultural, historical, religious factors in specific society. In these purposes a state uses proviso to international treaties replacing them with national-legal mechanisms.

Objective deficiencies are common to the international standards of human rights, which in some cases do not concretise acceptable level of human rights restriction. They establish impersonal norms, which do not take into account opportunity to perform them in specific state.

Institutional system of human rights protection in international level is also faced with problems its functioning. So, being tried to overcome its overload, the European court on human rights has established practice of making "pilot" orders, which is not always combined with Convention on protection of human rights and fundamental freedoms, and may deprive the ECHR its subsidiary nature. The UN Committee on human rights has lost an assignment, being not to be realized; its decisions have no any force, and therefore are not performed [4, p. 3-6]. 
It should especially be noted that problems of international system of human rights protection are tried to use as justification to establish "horizontal" system of human rights protection, when the states around the UN Security Council could be undertake forcible, including military measures to states, which do not fulfill its international commitments on human rights protection. This is fraught with danger collisions of interests [3, p. 110-111].

Enumerated list of issues is not exhausted. However, the more problems will be found the more opportunities will be appeared to synchronise and coordinate international and national laws in sphere of human rights and freedoms protection.

\section{References}

1. Izhikov M.Yu. Vzaimodeystvie mezhdunarodnogo i vnutrigosudarstvennogo prava $\mathrm{v}$ oblasti zaschity prav cheloveka [Cooperation of international and domestic laws in sphere of human rights protection]. Dis... kand. yurid. nauk [Diss. of $\mathrm{PhD}$ in Law]. Moscow, 2012, 218 p.

2. Efimichev S.P., Efimichev P.S. Vseobschaya deklaratsiya prav cheloveka I realizatsiya yeyo polozheniyi $\mathrm{v}$ sfere ugolovnogo sudoproizvodstva [Universal Declaration of Human Rights and performance its provisions in sphere of criminal proceedings] // Zhurnal Rossiyskogo prava [Russian Law Journal], no. 7/8, 1999, pp. 65-69.

3. Kartashkin V.A. Prava cheloveka v mezhdunarodnom i vnutrigosudarstvennom prave [Human rights in international and domestic laws]. Moscow, 1995, $135 \mathrm{p}$.

4. Nikolaev A.M. Mesto resheniyi Evropeyskogo Suda po pravam cheloveka v pravovoy sisteme Rossiyskoyi Federatsii [the place of decisions of European Court on Human Rights in legal system of Russian Federation]//Konstitutsionnoe i munitsipal'noe pravo [Constitutional and municipal laws], no. 17, 2007, pp. 3-6.

5. Khizhnyak V.S. Zakonomernosti, osobennosti i tendentsii razvitiya protsessa vzaimodeystviya natsional'nogo prava Rossii i mezhdunarodnogo prava [Regularities, particularities and trends of cooperation process development of national law of Russia and international law]. Saratov, 2003, 80 p. 